\title{
Relationship between pilot whales and Risso's dolphins at Santa Catalina Island, California, USA
}

\author{
Susan H. Shane \\ 250 Cottini Way, Santa Cruz, California 95060, USA
}

\begin{abstract}
Abundance of pilot whales at Santa Catalina 1sland, California, USA, declined from several hundred to between 0 and 33 per winter following the 1982-83 El Nin̄o-Southern Oscillation. Starting in 1987, abundance of Risso's dolphins, rarely seen before that time, increased. During a 9-winter-long study at Santa Catalina Island, parallels between the behavior and distribution of these 2 medium-sized, squid-eating delphinids were documented. One possibly aggressive encounter between pilot whales and Risso's dolphins was observed and others were reported. These factors led to the hypothesis that, while the ranges of these 2 species overlap, competitive displacement will generally prevent co-occurrence of these species in restricted geographic areas with limited food resources such as seen at Santa Catalina Island.
\end{abstract}

KEY WORDS: Pilot whale · Risso's dolphin · Competitive displacement · El Niño

\section{INTRODUCTION}

Short-finned pilot whales Globicephala macrorhynchus and Risso's dolphins Grampus griseus are medium-sized, squid-eating delphinids with overlapping cosmopolitan distributions throughout temperate and tropical waters. From at least the 1950 s until the early 1980s, pilot whales were fairly abundant in nearshore waters of southern California, USA [Norris \& Prescott 1961, Leatherwood et al. 1973 (cited in Evans et al. 1984), Dohl et al. 1981, Miller et al. 1983]. Estimates of pilot whale abundance at Santa Catalina Island (hereafter Catalina), California (see Fig. 1) during winter, when they gathered to feed on spawning market squid Loligo opalescens, ranged from about 300 (Miller et al. 1983) to about 1400 (Dohl et al. 1981). Sightings of Risso's dolphins by a variety of observers in southern California waters were rare from 1959 to 1975 (Leatherwood et al. 1980). Toward the end of that period, sightings of $G$. griseus over the continental shelf increased slightly (Leatherwood et al. 1980).

During the winters of 1983 to 1991, I studied pilot whale social organization at Catalina and recorded all cetacean sightings in Catalina waters, especially focusing on Risso's dolphins (Shane 1994). The first years of this study coincided with one of the most severe El Nino-Southern Oscillation (ENSO) events in 4 centuries (Quinn et al. 1987). A large increase in abundance of Risso's dolphins and a decrease in pilot whale abundance were observed throughout the Southern California Bight (SCB) during the 1980s (Barlow 1993; A. Schulman, American Cetacean Society, Los Angeles Gray Whale Census Project, PO Box 2639, San Pedro, CA, pers. comm.). During aerial surveys for pilot whales in southern California waters, Oliver \& Jackson (1987) sighted 1017 pilot whales in winter 1980-81, 311 in winter 1982-83, none in 1983-84, and just 49 in 1984-85. I observed similar shifts in abundance of pilot whales and Risso's dolphins at Catalina (Shane 1994), and the present study supports a connection between these changes at the local level.

Based upon my observations, I hypothesize that Risso's dolphins replaced pilot whales ecologically at Catalina after most of the latter disappeared during and following the 1982-83 ENSO. Further, I hypothesize that, while the 2 species often share the same distribution on a large scale (Leatherwood \& Reeves 1983, Polacheck 1987), competitive displacement probably is the rule on a small scale. In this paper I outline changes in occurrence and abundance of the 2 species, demonstrate the similarities between the local distribution and behavior of the 2 species, describe interactions 


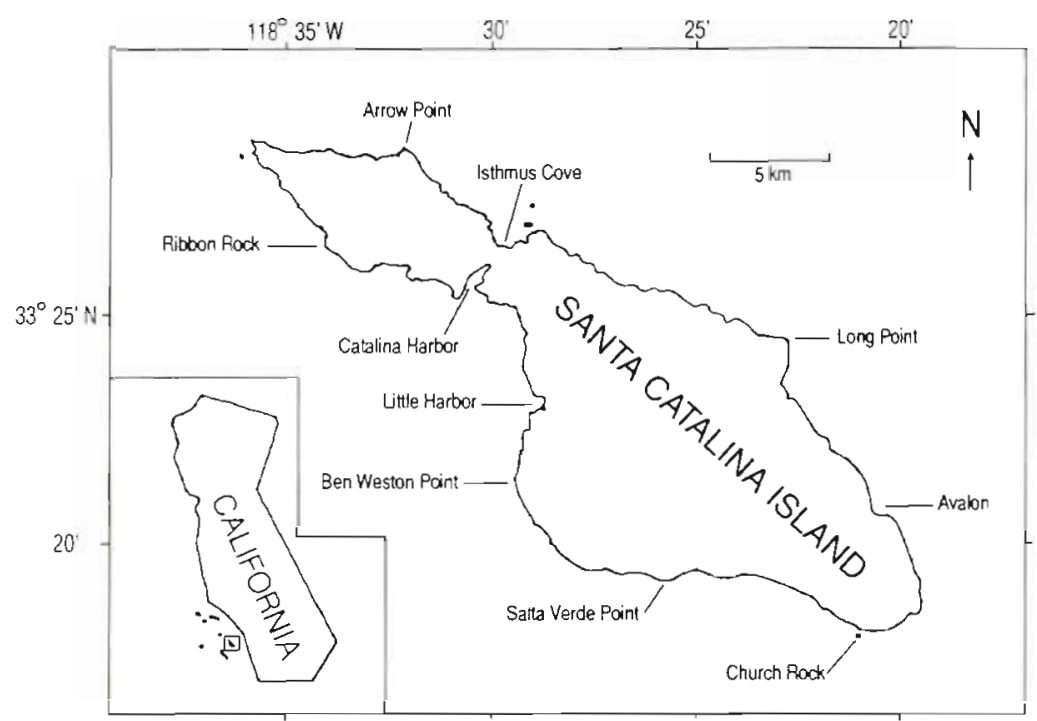

Fig. 1. Santa Catalina lsland, California, USA, site of 9 winters of research on pilot whales and Risso's dolphins

all squid boats seen around the island during the day. These boats usually were anchored and waiting for night fishing.

To test my hypothesis that competitive displacement would affect the distribution of pilot whales and Risso's dolphins on a small scale, I queried people who had conducted fairly large-scale marine mammal surveys to determine the frequency with which these 2 species had been sighted together.

\section{RESULTS}

\section{Abundance}

The abundance of pilot whales and Risso's dolphins fluctuated widely during this study (Fig. 2). Generally, pilot whales were most abundant during the first winter (1983) and were relatively rare there-

between them, and propose the possibility of competitive displacement of pilot whales by Risso's dolphins. I test my hypothesis of competitive exclusion using data from large-scale surveys by others in various parts of these species' ranges.

\section{METHODS AND MATERIALS}

Field work at Catalina lasted from 3 d (1990) to 4 mo (1983-84 and 1984-85) each winter from 1983 to 1991. A total of $905 \mathrm{~h}$ was spent searching for pilot whales and other marine mammals on $283 \mathrm{~d}$. Typically, an observer and I traveled in a $5 \mathrm{~m}$ Boston Whaler with an 85 or $70 \mathrm{hp}$ outboard engine along a portion of the Catalina coastline or circumnavigated the island at a distance of 0.4 to $1.6 \mathrm{~km}$ offshore. Each observer scanned $180^{\circ}$ on his/her side of the boat. Whenever cetaceans were sighted, we stopped to identify the species and count the number of individuals. We also recorded the date, time, location, water depth, distance offshore, behavioral state, direction and speed of travel, and group geometry.

I compared daily counts of pilot whales and Risso's dolphins to discover whether they were significantly associated (Spearman rank correlation coefficient). I excluded data from 1983, because I did not count pilot whales consistently when I observed them that year.

In most years, we scanned for and counted squid fishing boats at night between Arrow Point and Long Point (Fig. 1). Squid boats fish only at night and are easily identified by the bright lights hanging off their sides to attract squid to the surface. We also recorded after. Risso's dolphins were seen rarely until 1987 when they became the most abundant cetacean in Catalina waters. There was a highly significant inverse correlation between daily counts of the 2 species $\left(r_{S}=\right.$ $-0.80, p<0.0001, N=58$ ).

Two factors that reflected major environmental changes taking place during the study were sea surface temperature (SST) and commercial squid catch. The 1982-83 ENSO had its most profound effects at Catalina in 1983-84 (McGowan 1985). While SSTs at Catalina were anomalously high during the 1980s in comparison with the long-term average (Brainard \& McLain 1985; see also Strong 1987, Reynolds et al. 1989 for contrasting views on long-term warming trends in the 1980s), SSTs were highest in the winters of 1983 and 1984 (Fig. 3). More moderate ENSOs occurred in 1987 (Quinn et al. 1987) and 1990-92 (Pearce 1993).

The increased SST in 1983-84 had severe effects upon the marine ecosystem (McGowan 1984, Pearcy \& Schoener 1987). Most important for the cetaceans I studied was the nearly complete disappearance of market squid, the chief food item for pilot whales (Seagars \& Henderson 1985, Sinclair 1992) and Risso's dolphins (Kruse 1989). Market squid aggregate at Catalina and elsewhere in southern California waters every winter to spawn (Fields 1965). Commercial squid landed in the Los Angeles area are mostly caught around Catalina and are taken as an indication of relative changes in squid abundance there (Fig. 2). Squid catches dropped drastically in 1983, fell to near zero in 1984 and finally reached their pre-ENSO levels in 1986. 

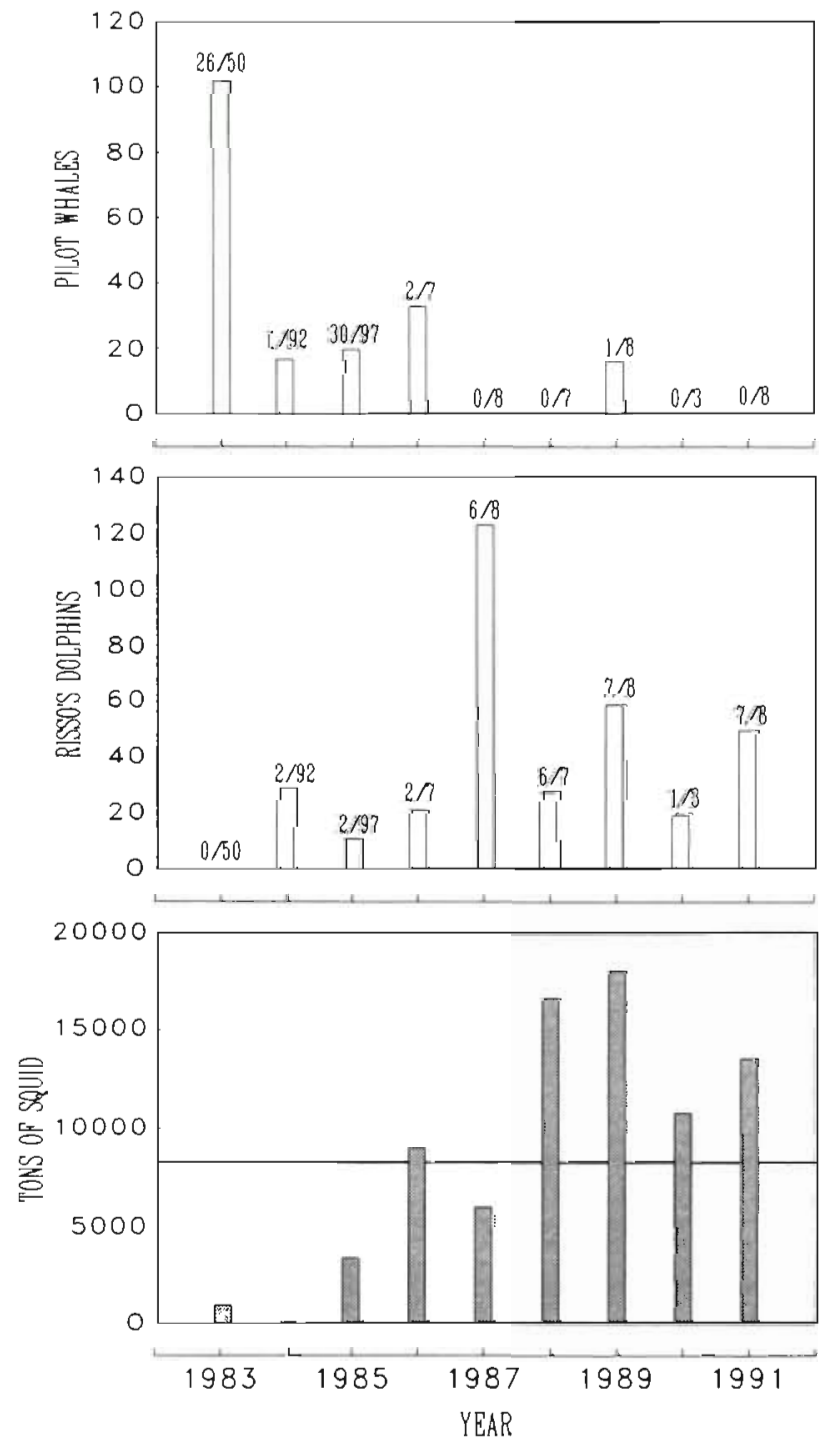

Fig. 2. Globicephala macrorhynchus, Grampus griseus, and Loligo opalescens. Abundance of pilot whales and Risso's dolphins and commercial squid catch. Abundance graphs show the highest daily counts of pilot whales and Risso's dolphins during 9 winters at Catalina. Numbers above each bar indicate the number of days that a species was seen out of the total number of search days for that year. The lower graph shows market squid landed in the Los Angeles area. Much of this squid was caught around Santa Catalina Island (California Dept of Fish and Game pers. comm.). Horizontal line: average squid catch from 1977 to 1981

\section{Distribution around island}

There was a strong association between the distribution of pilot whales and Risso's dolphins and the distribution of commercial squid fishing boats around Catalina (Table 1).

Pilot whales were seen most frequently ( $76 \%$ of 317 records) between 0.1 and $0.8 \mathrm{~km}$ offshore and in

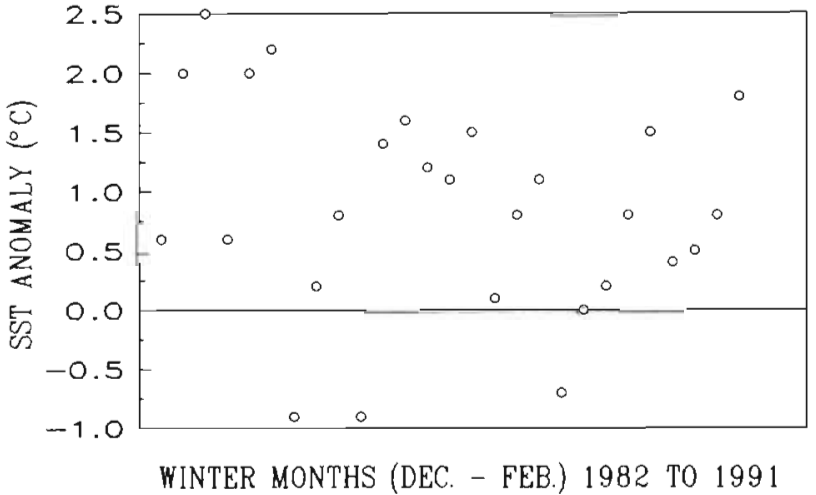

Fig. 3. Anomalies in monthly sea surface temperatures (SST) at Catalina during 9 winters (December-February). Data begin in December 1982 and end in February 1991 The monthly anomaly is the difference between the mean monthly SST and the long-term average monthly SST recorded by National Atmospheric and Oceanic Administration (NOAA. 1982-1991) satellites. The long-term average monthly mean SST (1942-1981) for relevant months was: December $15.9^{\circ} \mathrm{C}$; January $14.1^{\circ} \mathrm{C}$; February $13.5^{\circ} \mathrm{C}$

Table 1 Number of squid fishing boats counted each year at Catalina. 'Area(s) in which most pilot whales and/or Risso's dolphins were aggregated each year. The second year of the study (1983-84) is omitted, because both species were sighted only briefly. No squid boats were seen in 1986. Areas (see Fig. 1): I: Isthmus Cove to Arrow Point; II: Arrow Point to Ribbon Rock; III: Catalina Harbor to Ben Weston Point; IV: Ben Weston Point to Salta Verde Point; V: Salta Verde Point to Church Rock; VI: Church Rock to Avalon; VII: Avalon to Long Point

\begin{tabular}{|c|c|c|c|c|c|c|c|}
\hline \multirow[t]{2}{*}{ Year } & \multicolumn{7}{|c|}{ Area } \\
\hline & I & II & III & IV & V & VI & VII \\
\hline 1983 & $194^{*}$ & 3 & 5 & 5 & 5 & & \\
\hline $1984-85$ & 74 & 3 & & $25^{\circ}$ & & & \\
\hline 1987 & & $15^{\circ}$ & 1 & & & & \\
\hline 1988 & $\cdot$ & & & & & & $12^{\circ}$ \\
\hline 1989 & & & & $3^{\circ}$ & $\cdot$ & $1^{\circ}$ & \\
\hline 1990 & & & $2^{\circ}$ & & & & \\
\hline 1991 & $16^{\circ}$ & & & & & & \\
\hline
\end{tabular}

shallower water than Risso's dolphins (Fig. 4, Table 2). Pilot whales moved into deeper than usual waters to feed, while Risso's dolphins moved into shallower than usual waters to feed (Table 2).

\section{Respiration patterns}

Respiration patterns give some indication of a cetacean's use of its environment. Both pilot whales and Risso's dolphins occasionally exhibited a pattern of one long dive, during which all pod members were submerged for an extended period, followed by a 
Table 2. Globicephala macrorhynchus and Grampus griseus. Mean depth of water $\left(m_{1} \pm S D\right)$ where pilot whales and Risso's dolphins were sighted at Catalina from 1983 to 1991

\begin{tabular}{|lrrrr|}
\hline Behavior & Pilot whales & N & Risso's dolphins & N \\
\hline All & $35.3 \pm 18.13$ & 204 & $85.8 \pm 26.07$ & 143 \\
Traveling & $32.8 \pm 18.57$ & 148 & $87.1 \pm 27.43$ & 110 \\
Feeding & $43.7 \pm 15.71$ & 43 & $58.9 \pm 5.37$ & 3 \\
\hline
\end{tabular}

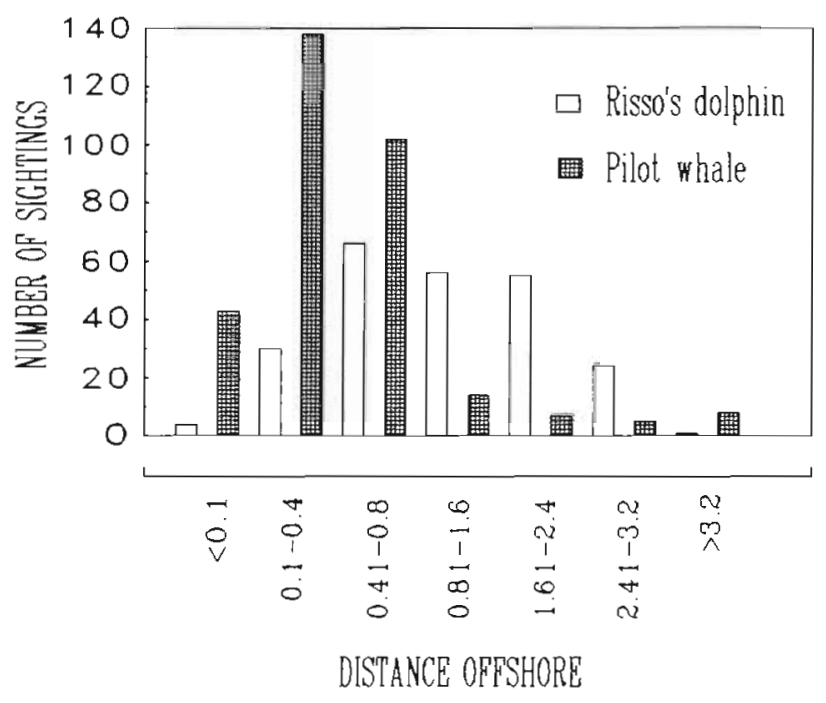

Fig. 4. Globicephala macrorhynchus and Grampus griseus. Frequency of sighting pilot whales $(\mathrm{n}=317)$ and Risso's dolphins $(n=236)$ at various distances offshore (in $\mathrm{km})$

period in which the cetaceans remained near the surface and submerged briefly in a series of several short dives before making another long dive (Table 3).

\section{Interspecific relationships}

Bottlenose dolphins were frequently observed with both pilot whales and Risso's dolphins. Out of 149 total sightings, bottlenose dolphins were found swimming with other cetaceans 81 times. On 57 occasions they were with pilot whales and 14 times with Risso's dolphins (Shane 1994).

I observed pilot whales and Risso's dolphins together only 1 time. Table 4 summarizes the events observed before, during and after that encounter. Pilot whales, perhaps the same pod of 33 seen on the occasion described in Table 4, had been observed intermittently at Catalina by other researchers since mid-December 1985. We had observed this pod of 33 pilot whales $2 \mathrm{~d}$ before the encounter with Risso's dolphins; we had not
Table 3. Globicephala macrorhynchus and Grampus griseus Respiration patterns (time, in minutes) for pilot whales and Risso's dolphins at Catalina from 1983 to 1991 These data were collected only during times when a pattern of long dives, interrupted by an interval including several short dives, was occurring. This diving pattern was seen relatively infrequently for both species

\begin{tabular}{|c|c|c|c|c|c|c|}
\hline & \multicolumn{3}{|c|}{ Pilot whales } & \multicolumn{3}{|c|}{ Risso's dolphins } \\
\hline & $\bar{x}$ & $\mathrm{SD}$ & $\mathrm{N}$ & $\bar{x}$ & $\mathrm{SD}$ & $N$ \\
\hline $\begin{array}{l}\text { Long dive } \\
\text { submergence } \\
\text { time }\end{array}$ & 2.6 & 1.24 & 71 & 2.1 & 0.58 & 84 \\
\hline $\begin{array}{l}\text { Interval } \\
\text { between long } \\
\text { dives (including } \\
\text { several short } \\
\text { dives) }\end{array}$ & 2.4 & 0.97 & 56 & 2.0 & 0.67 & 72 \\
\hline $\begin{array}{l}\text { Short dive } \\
\text { submergence } \\
\text { time }\end{array}$ & 0.32 & 0.15 & 29 & 0.25 & 0 & 4 \\
\hline
\end{tabular}

been in the field the day before the encounter. We searched for pilot whales for $3 \mathrm{~d}$ following this encounter but were unable to sight any.

Additional encounters between these 2 species at Catalina were recorded by S. Lafferty (pers. comm.), a naturalist at Los Angeles County Museum of Natural History (900 Exposition Blvd, Los Angeles, CA), on 11-12 February 1989. On both days Risso's dolphins approached a pod of pilot whales at Little Harbor on Catalina. In both instances tail slapping and splashing were seen during the encounter, and on one day the pilot whales swam away from the Risso's dolphins and formed a tight cluster.

Schulman (pers. comm.) reported that, during a census for gray whales from Pt. Vicente, California (approximately $30 \mathrm{~km}$ from Catalina), pilot whales and Risso's dolphins were sighted together on 11 January 1987. A pod of pilot whales was followed into a cove $0.2 \mathrm{~km}$ offshore by Risso's dolphins which had never before been seen so close to shore.

\section{DISCUSSION}

The dramatic decline in pilot whale abundance at Catalina corresponded with the near-disappearance of market squid from the area (Fig. 2), which, in turn, was a response to the environmental changes caused by ENSO (Fig 3). While I observed single pods of pilot whales at Catalina in some years following the strong 1982-83 ENSO, I never again encountered the large aggregations found there throughout the winter prior to 1983 (Norris \& Prescott 1961, Dohl et al. 1981, Oliver 
Table 4. Globicephala macrorhynchus and Grampus griseus. Summary of an encounter between pilot whales (GM) and Risso's dolphins (GG) at Catalina on 9 February 1986

\begin{tabular}{ll} 
Time $(\mathrm{h})$ & \multicolumn{1}{c}{ Events } \\
\hline 08:55-13:30 & $\begin{array}{l}\text { 33 GM (including 1 calf, } 1 \text { juvenile and } 31 \text { medium-sized adults) slowly travel back and forth along coast } \\
\text { within 0.5 km of shore. Rest occasionally. Feed once. Two largest whales (with whitened leading edges of } \\
\text { dorsal fins) often position themselves between our boat and rest of pod. Group geometry fluctuates }\end{array}$ \\
$\begin{array}{ll}\text { 13:30-13:40 GM travel rapidly in distunct subpods. Lots of head and trunk slapping, leaping and vigorous tail slapping } \\
\text { A group of } 9 \text { to } 11 \text { GG arrive, swimming widely dispersed and moving in varying directions }\end{array}$ \\
$\begin{array}{ll}\text { GM tightly cluster together, milling and resting 250-500 m offshore. Three GM, including the } 2 \text { largest, are } \\
\text { separate from rest of GM and closer to GG which continue to move in varying directions }\end{array}$
\end{tabular}

\& Jackson 1987). Thirteen marine mammal researchers between southern California and Oregon, USA, reported no increase in pilot whale abundance elsewhere (Shane 1984). Webber et al. (1989) reported only 1 sighting of 3 pilot whales in 1984 during surveys at the Gulf of the Farallones, California, in 1983-87. Except for 1 sighting of 150 pilot whales off British Columbia, Canada, in August 1986, few pilot whales were recorded in British Columbian waters during my study period ( $\mathrm{N}=12$ sightings from 1985 to 1989 ; Baird \& Stacey 1993). I compared 47 photoidentified Catalina pilot whales with photos taken of pilot whales in the eastern tropical Pacific ( $N=10$ individuals, 18 October 1983; S. Beavers, Oregon State Univ., pers. comm.) and off coastal California and Mexico ( $N=14$ individuals, August and October 1993; T. Gerrodette, NMFSSWFSC, PO Box 271, La Jolla, CA, pers. comm.). No matches were made. Thus, the fate of the pilot whales that once were sighted routinely in the SCB is unknown.

In 1987 a large aggregation of about 120 Risso's dolphins appeared nearshore at Catalina in the vicinity of the commercial squid boats (Fig. 2, Table 1). Annually thereafter, Risso's dolphins were seen routinely associated with squid boats (Table 1), and they appeared to be resident during my field period. Risso's dolphins are generally considered to be a pelagic species which is found nearshore primarily during periods of increased SST (Leatherwood et al. 1980, Dohl et al. 1981, Kruse 1989). The initial increase in nearshore abundance of Risso's dolphin at Catalina corresponded with a moderate 1987 ENSO (Fiedler et al. 1992). However, during the strong 1957-58 ENSO (Quinn et al. 1987 ), Norris \& Prescott (1961) reported no sightings of Risso's dolphins in the SCB.

The significant correlation between daily counts of the 2 species $\left(r_{S}=-0.80\right)$ shows that the abundance of pilot whales was inversely associated with the abundance of Risso's dolphins. My hypothesis that Risso's dolphins replaced pilot whales ecologically at Catalina, in essence occupying the same niche (May 1981), is supported by the following findings which suggest that both species exploit the same resource, market squid, in the same way: (1) the association between the distribution of both species and that of commercial squid boats; (2) the shift both species make into 40 to $60 \mathrm{~m}$ deep water to feed during the day (deeper than average for pilot whales and shallower than average for Risso's dolphins); Fields (1965) reported that market squid lay their eggs in waters from 3 to more than $36 \mathrm{~m}$ deep; (3) the similarity in respiration patterns between the 2 species; and (4) the strong attraction that bottlenose dolphins have toward both species; Shane (1994) argued that bottlenose dolphins are attracted to the larger odontocetes, because the latter may increase the dolphins' ability to acquire food.

My hypothesis of competitive displacement in a restricted geographic area originated for 2 reasons: (1) the inverse shift in abundance of the 2 species during my 9 yr study; (2) my own observation of the 2 species interacting on 9 February 1986. I interpreted the $10 \mathrm{~min}$ of vigorous surface displays by pilot whales before the Risso's dolphins arrived to be a possible attempt to discourage the Risso's dolphins from approaching closer. I interpreted the pilot whales' huddling behavior upon the arrival of the Risso's dolphins as defensive. The interposition of 3 pilot whales, including the 2 largest and possibly oldest, between their fellow pod members and the Risso's dolphins also appeared to be a defensive maneuver. When pilot whales disappeared from Catalina the day following this encounter, I further suspected that the Risso's dolphins had actively displaced the pilot whales. Such displacement is a form of interference competition (May 1981, Barta et al. 1989).

The encounters between Risso's dolphins and pilot whales reported to me by Lafferty and Schulman were similar to my own observation. In all instances, the Risso's dolphins approached the pilot whales, rather than vice versa. Tail slapping, an aggressive cetacean behavior, was reported in 3 of the 4 encounters. Although Risso's dolphins are somewhat smaller than pilot whales 
Table 5. Globicephala macrorhynchus and Grampus griseus. Number of sightings of pilot whales (GM) and Risso's dolphins (GG) alone and mixed together in 6 large marine mammal surveys around the United States. Survey areas and sources of data: (1) MOPS: eastern tropical Pacific and (2) coastal California from shore to $650 \mathrm{~km}$ offshore: Marine Mammal Division, NMFS-SWFSC (pers. comm.); (3) Gulf of Mexico from Florida/Alabama border to Texas and 100 to $2000 \mathrm{~m}$ isobaths: T. Jefferson and Dr B. Würsig, Texas A\&M University (pers. comm.); (4) Gulf of Mexico, $87^{\circ} 30^{\prime}$ to $91^{\circ}$ from south of Mississippi River delta to $44 \mathrm{~km}$ south of $200 \mathrm{~m}$ isobath; (5) Gulf Cet Aerial, Gulf of Mexico $87^{\circ}$ to $91^{\circ}, 100$ to $2000 \mathrm{~m}$ isobaths and $91^{\circ}$ west, 100 to $1000 \mathrm{~m}$ isobaths; (6) Gulf Cet Ship, U.S. Gulf of Mexico beyond $200 \mathrm{~m}$ isobath: K. Mullin, NMFS (pers. comm.)

\begin{tabular}{|c|c|c|c|c|}
\hline Survey & Dates & GM & $\mathrm{GG}$ & Mixed \\
\hline 1 & $1986-90,1992$ & 321 & 279 & $3^{a}$ \\
\hline 2 & $1991,1993,1979-85$ & 40 & 190 & 0 \\
\hline 3 & $1992-93$ & 3 & 5 & 0 \\
\hline 4 & $1989-90$ & 5 & 61 & $1^{b}$ \\
\hline 5 & $1992-93$ & 8 & 19 & 0 \\
\hline 6 & $1990-93$ & 8 & 47 & 0 \\
\hline
\end{tabular}

(3.6 to 4 vs 4 to $5.4 \mathrm{~m}$ respectively; Leatherwood \& Reeves 1983), they appear to be more aggressive. For instance, Shelden et al. (1993) described Risso's dolphins pursuing and encircling gray whales.

I tested my hypothesis of competitive exclusion by investigating sighting results from 6 cetacean surveys and found that, out of a cumulative total of 989 sightings of pilot whales and Risso's dolphins, only 4 sightings $(0.4 \%)$ were of the 2 species together (Table 5). Additionally, during surveys in the central Mediterranean Sea from 1986 to 1993 (Notarbartolo 1993, G. Notarbartolo-di-Sciara, Tethys Research Inst., Via Giusti 5, Milan, Italy, pers. comm.), long-finned pilot whales and Risso's dolphins were seen separately, 12 and 47 times respectively, but never together. In fact, in the Mediterranean these 2 species occupied different habitats; pilot whales were pelagic (mean depth $2196 \mathrm{~m})$, while Risso's dolphins inhabited the outer slope (mean depth $991 \mathrm{~m}$ ). Dohl et al. (1981) did not find pilot whales and Risso's dolphins together during their 3 yr survey of SCB waters. All of these studies lend support to my hypothesis that pilot whales and Risso's dolphins compete for similar resources and so are not likely to co-occur. One somewhat contrary finding was that of Fiscus \& Niggol (1965), who described pilot whales accompanying Risso's dolphins in 3 out of 10 sightings off central California between 1958 and 1961.

Polacheck (1987) found a correlation coefficient of 0.389 for pilot whales and Risso's dolphins based on encounter rates in $5^{\circ}$ squares within the eastern tropical Pacific between 1977 and 1980. He identified these species, among others, as 'potentially major competi- tors' and surmised that some sort of resource partitioning must be taking place for the species to co-occur. Throughout the range of these 2 species, they may, indeed, have partitioned the potentially limiting resource, squid. The 2 delphinids may feed on different species or sizes of squid, for instance. At Catalina in winter, there is only 1 species and size of squid aggregated for spawning in a relatively small geographic area. Other predators such as bottlenose dolphins, California sea lions and seabirds (especially gulls) concentrate at times around the commercial squid boats, presumably also to feed on squid. Squid at Catalina in winter seem to be a limited resource, setting the stage for competition and displacement.

There were several limitations in this study. I cannot unequivocally demonstrate that pilot whales and Risso's dolphins feed exclusively on market squid at Catalina in winter, and it is not known if squid are, in fact, a limiting resource for these species. My interpretation of the pilot whale - Risso's dolphin interactions as aggressive and, thus, an indication of interference competition could be incorrect. Factors other than competition could account for the rarity of sighting these 2 species together. Despite these limitations, I believe the evidence for possible competition is intriguing and useful to present, because little is known about competition among cetaceans. I hope these hypotheses will be explored in more depth by others.

In summary, circumstantial evidence indicated that pilot whales and Risso's dolphins both aggregated to feed on market squid at Catalina in winter. Further, these delphinids used the habitat similarly, presumably feeding mostly at night and traveling and resting or socializing during the day. Observations of direct encounters between the species were interpreted as possibly aggressive and suggestive of interference competition. Large-scale surveys in various parts of the 2 species' ranges showed that the 2 were almost never sighted together, suggesting possible competitive exclusion or displacement on a local scale.

Acknowledgements. I am very grateful to the following people who so generously shared their unpublished data with me: Steve Reilly, Tom Jefferson, Bernd Wüsig, Keith Mullin, Giuseppe Notarbartolo-dj.Sciara, Tim Gerrodette, Alisa Schulman, and Sue Lafferty. Drafts of this paper were reviewed by Bernd Würsig, Beth Mathews, Tim Gerrodette, Steve Reilly, Jay Barlow, and anonymous reviewers. I am grateful to Sallie Beavers and Tim Gerrodette for help with 
statistics. Field assistants during this study included Craig Strang, Sallie Beavers, Michael Poole, Jan Östman, Becky Rumsey and Sara Heimlich-Boran. Funding was received from the Southwest Fisheries Science Center of the National Marine Fisheries Service, the U.S Marine Mammal Commission, the Theodore Roosevelt Memorial Fund of the American Museum of Natural History, the Monterey Bay Chapter of the American Cetacean Society, and the Biology Board of the University of California at Santa Cruz. This work was conducted under Marine Mammal Protection Act permit no. 624.

\section{LITERATURE CITED}

Baird RW, Stacey PJ (1993) Sightings, strandings and incidental catches of short-finned pilot whales, Globicephala macrorhynchus, off the British Columbia coast. In: Donovan GP, Lockyer $\mathrm{CH}$, Martin AR (eds) Biology of northern hemisphere pilot whales. Rept of the International Whaling Commission, Spec Issue 14, Cambridge, UK, p 475-479

Barlow J (1993) The abundance of cetaceans in California waters estimated from ship surveys in summer/fall 1991 Admin Rep LJ-93-09. National Marine Fisheries Service, Southwest Fisheries Science Center, La Jolla, CA

Barta RM, Keith LB, Fitzgerald SM (1989) Demography of sympatric arctic and snowshoe hare populations: an experimental assessment of interspecific competition. Can J Zool 67:2762-2775

Brainard RE, McLain DR (1985) Subsurface temperature variability along the west coast of North and South America. Trop Ocean-Atmos Newsl 31:1-2

Dohl TP, Norris KS, Guess RC, Bryant JP. Honig MW (1981) Cetacea of the Southern California Bight, Vol III, Part 2, Principal investigator's reports. Summary of marine mammal and seabird surveys of the Southern California Bight area 1975-78. Final report to the Bureau of Land Management. NTIS PB81-248-171. National Technical Information Service, Springfield, VA

Evans WE, Thomas JA, Kent DB (1984) A study of pilot whales (Globicephala macrorhynchus) in the Southern California Bight. Admin Rep LJ-84-38C. National Marine Fisheries Service, Southwest Fisheries Center, La Jolla, CA

Fiedler PC, Chavez FP, Behringer DW, Reilly SB (1992) Physical and biological effects of Los Niños in the eastern tropical Pacific, 1986-1989. Deep Sea Res 39:199-219

Fields WG (1965) The structure, development, food relations, reproduction, and life history of the squid Loligo opalescens Berry. Calif Dept Fish Game, Fish Bull 131:1-108

Fiscus $\mathrm{CH}$, Niggol K (1965) Observations of cetaceans off California, Oregon, and Washington. Special Scientific Rep, Fisheries No. 498. US Fish \& Wildlife Service, Washington, DC

Kruse SL (1989) Aspects of the biology, ecology, and behavior of Risso's dolphins (Grampus griseus) off the California coast. MSc thesis, University of California, Santa Cruz

Leatherwood S, Lingle GE, Evans WE (1973) The Pacific pilot whale, Globicephala spp. Naval Undersea Center Tech Note 933

Leatherwood S, Perrin WF, Kirby VL, Hubbs CL, Dahlheim M (1980) Distribution and movements of Risso's dolphin, Grampus griseus, in the eastern North Pacific. Fish Bull US 77:951-963

Leatherwood S, Reeves RR (1983) The Sierra Club handbook of whales and dolphins. Sierra Club Books, San Francisco

May RM (1981) Models for two interacting populations. In: May RM (ed) Theoretical ecology, 2nd edn. Sinauer Assoc,
Sunderland, MA, p 78-104

McGowan JA (1984) The California El Niño, 1983. Oceanus $27: 48-51$

McGowan JA (1985) El Niño in 1983 in the Southern California Bight. In: Wooster WS, Fluharty DL (eds) El Niño north: Niño effects in the eastern subarctic Pacific Ocean. Washington Sea Grant Program, University of Washington, Seattle, p 166-184

Miller DM, Herder M, Scholl J (1983) California marine mammal-fishery interaction study, 1979-1981. Admin Rept LJ-83-13C. National Marine Fisheries Service, Southwest Fisheries Center, La Jolla, CA

NOAA (1982-1991) Oceanographic monthly summary. National Oceanic and Atmospheric Administration, National Weather Service, Vol II-XI, No 1-12

Norris KS, Prescott J (1961) Observations on Pacific cetaceans of Californian and Mexican waters. Univ Calif Publs Zool 63:291-402

Notarbartolo-di-Sciara G (1993) Habitat preferences by cetaceans in the central Mediterranean Sea. Abstract, 10th Biennial Conference on the Biology of Marine Mammals, Galveston, TX, Nov 11-15, 1993

Oliver CW, Jackson TD (1987) Occurrence and distribution of marine mammals at sea from derial surveys conducted along the U.S. west coast between December 15, 1980 and December 17, 1985. A.dmin Rep LJ-87-19. National Marine Fisheries Service, Southwest Fisheries Center, La Jolla, CA

Pearce F (1993) El Nin̄o roars back against the odds. New Sci 138:7

Pearcy WG, Schoener A (1987) Changes in the marine biota coincident with the 1982-1983 El Nino in the northeastern subarctic Pacific Ocean. J geophys Res 92:14417-14428

Polacheck T (1987) Relative abundance, distribution and inter-specific relationship of cetacean schools in the eastern tropical Pacific. Mar Mamm Sci 3:54-77

Quinn WH, Neal VT, Antunez de Mayolo SE (1987) El Niño occurrences over the past four and a half centuries. J geophys Res 92:14449-14461

Reynolds RW, Folland CK, Parker DE (1989) Biases in satellite-derived sea-surface-temperature data. Nature 341: $728-731$

Seagars DJ, Henderson JR (1985) Cephalopod remains from the stomach of a short-finned pilot whale collected near Santa Catalina Island, California. J Mamm 66:777-779

Shane SH (1984) Pilot whales and other marine mammals at Santa Catalina Island, California in 1983-84. Admin Rep LJ-84-28C. National Marine Fisheries Service, Southwest Fisheries Center, La Jolla, CA

Shane SH (1994) Occurrence and habitat use of marine mammals at Santa Catalina Island, California from 1983-91. Bull Sth Calif Acad Sci 93:13-29

Shelden KEW, Baldridge A, Withrow DE (1993) Observations of Risso's dolphins, Grampus griseus, with gray whales, Eschrichtius robustus. Mar Mamm Sci 11(2):231-240

Sinclair EH (1992) Stomach contents of four short-finned pilot whales (Globicephala macrorhynchus) from the Southern California Bight. Mar Mamm Sci 8:76-81

Strong AE (1987) Greater global warming revealed by satellite-derived sea-surface-temperature trends. Nature 338: 642-645

Webber MA, Szczepaniak ID, Ewald C, Markowitz H (1989) Marine mammal sightings in the Gulf of the Farallones, California, June-November, 1983-1987. Abstract, 8th Biennial Conference on the Biology of Marine Mammals, Pacific Grove, CA, Dec 7-11, 1989 